International Journal of Advanced Trends in Computer Science and Engineering

Available Online at http://www.warse.org/IJATCSE/static/pdf/file/ijatcse37932020.pdf

https://doi.org/10.30534/ijatcse/2020/37932020

\title{
Analysis Loyalty in Video Conference Application Zoom on COVID 19 Quarantine in Jakarta
}

\author{
Aditya Putri Pertiwi ${ }^{1}$, Devi Puri ${ }^{2}$, Yogie Ajie Pratama ${ }^{3}$, Sfenrianto ${ }^{4}$, Gunawan Wang ${ }^{5}$ \\ ${ }^{12345}$ Information Systems Management Department, BINUS Graduate Program - Master of Information Systems \\ Bina Nusantara University, Jakarta, Indonesia, 11480. \\ ${ }^{1}$ Aditya.pertiwi@binus.ac.id, 2Devi.puri001@binus.ac.id, ${ }^{3}$ yogie.pratama002@binus.ac.id, \\ ${ }^{4}$ Sfenrianto@binus.edu, ${ }^{5}$ gwang@binus.edu
}

\begin{abstract}
The effect of the coronavirus outbreak towards Jakarta residents is an enactment of large-scale social restrictions regulation to prevent virus transmission. Work from home also causing an increase in video conference user data traffic. Zoom application is experiencing the number of users increase throughout March 2020. Even so, some people start doubting the Zoom user data security. Therefore, the question in this research is how trust impacts on video conference application user loyalty in Jakarta.
\end{abstract}

Key words : Video Conference Application, Trust, Customer Loyalty, Covid-19

\section{INTRODUCTION}

The impact of the coronavirus outbreak on Jakarta residents is an enactment of large-scale social restrictions regulation to prevent virus transmission. Therefore, all activities such as study, work, and worship service are performed at home. To keep the communication while staying home for working and learning there is a required communication media. One of the many communication media that is mostly used is video conference application.

Working from home also effecting an increase in video conference application user data traffic. Two applications that have a significant increase are Zoom and Google Hangouts that are recorded to increase 20 until 23 percent of the user. This increase of user data is significant enough because, before the Covid-19 pandemic, those two applications can be said as rarely used. Besides those two applications, almost all conference video services are experiencing user enhancement [1].

Based on data in katadata.co.id, Zoom application experiencing some users increment throughout March 2020, but the user increment is accompanied by the worry from some people about Zoom security. In December 2019, Zoom application users globally recorded only reach 10 million daily users. In the last few weeks, Zoom has been used by more than 90.000 education institutions to perform online teaching and learning activities in 20 countries. Based on an analysis by JP Morgan, the total of Zoom daily active users was increasing by $378 \%$ yearly (year on year/YoY) in March 2020. While based on Apptopia data, Zoom monthly active users were recorded jump up to $186 \%$.

Even so, some circles starting from a rocket maker company that is founded by Elon Musk, SpaceX, to The Federal Bureau of Investigation (FBI) of the United States are doubting Zoom security. SpaceX has announced that all employees' access to the Zoom application has been dis-activated since last week (28/3). SpaceX then appealed their employees to use another communication service in the middle of this corona pandemic.

SpaceX's reason is Zoom user data security can't be trusted. Whereas SpaceX is a technology company that has a high standard regarding data security for United States national importance. FBI also warned schools about the risk of Zoom default settings. New York Attorney General Office also sent a letter to Zoom to ask for a clarification related to the effort on maintaining Zoom user data security. Zoom also has faced lawsuits in California and on charged of user private information collection without prior adequate notice. They also accused Zoom of giving that private information to a third party, including Facebook. After a lot of criticism because of the security issue, Yuan has apologized to hundreds of million Zoom application users.

Zoom has pleaded sorry and stopped adding a new feature for the next 90 days. Then, Zoom stated they will be focusing on resolving security issues in their application. Zoom will periodically release their transparency report, similar to the action of some tech giants have done such as Facebook, Twitter, and Google. All three indeed are detailed in their report regarding data requests or content from a 
governmental authority. The impact of security issues is Zoom's share is slipping too. On Thursday (2/4) Zoom's share is weakened to $11 \%$. Even so, Zoom's share is recorded has increased since the corona pandemic. Quoted from Forbes, on Wednesday (25/3), Zoom stock price reached US\$ 106,8 similar to Rp 1,7 million. That achievement is the highest level of stock price throughout Zoom history [2].

From the background which already explained about user increment and doubts on Zoom video conference application service security, then Author is interested to do a research on Analysis of Trust and Service Security Impact on User's Loyalty of Zoom Video Conference Application.

\section{LITERATURE REVIEW}

\section{A. Video Conference}

Video conference is a part of long-distance online learning or can be defined as communication media that can be used for multiple activities such as lecture, tutorial, project review, also long-distanced visits. Video conferencing consist of point-to-point or multipoint, which connecting three sites or more with voices and visual (video) in real-time. Technically, video conferencing multipoint is harder. Video conferencing also has a feature to share the data used by all members electronically [3].

\section{B. Zoom in Covid 19}

An unknown virus that appeared from Wuhan, China, and has spread across the country and world by the end of December 2019. This virus has been named Coronavirus Disease-2019 but on February 11th ,2020, WHO has named it as COVID-19. The symptoms stated by the Ministry of Health in Taiwan CDC of the virus such as severe pneumonia and have been reported as the fifth category of infectious diseases. COVID-19 is an animal disease that can be transmitted to humans or can be called as a zoonotic disease. The mortality rate of this disease is low to moderate with an estimation of $2 \%-5 \%$. Transmission among people can happen through physical contact or droplets or if the is no sufficient infection equipment it can harm the health workers [4]. The COVID-19 pandemic has reached Indonesia in March 2020 and started with 2 confirmed COVID-19 infected people on March 2nd, 2020. The virus continued spreading through all over Indonesia and has been recorded of 5,923 people had been infected on April 17th, 2020 [5].

The use of the Zoom teleconference application is skyrocketing lately, especially since the corona virus pandemic. Not a few people who use Zoom to work and learn from home. But unfortunately, this application is troubled by problems because it is called sharing Zoom user's personal data to social media Facebook. Not to mention the teleconference in Zoom is also not encrypted end-to-end, so it does not protect the user completely. Despite these concerns, businesses, schools and even the government continue to use the Zoom application to hold meetings and presentations. Meanwhile, zoom is a popular platform for friends and family to meet virtually. There was no response on this matter from Zoom, but Zoom founder Eric Yuan said that the company sincerely apologized for the concerns caused by this in a blog post last week. With Zoom becoming more and more popular, its security practices are also attracting more attention from people, because not long ago there were also cases of hackers sneaking into ongoing video conferences[6].

\section{Customer Loyalty}

Customer' s loyalty is a commitment to thoroughly maintain whether to go back or consistently subscribing to a chosen product or service. The loyalty concept is more directed at the behavior of a unit or decision-maker long-term purchase [7].

\section{Trust}

Trust is defined as the general expectation that is held by an individual on another person that is reliable or customer's view as thought, feeling, emotion, or behavior when the customer feel that service provider is reliable to act [8].

\section{E. Satisfaction}

Satisfaction is feeling or behavior when purchasing or using a service or product from a company to fulfill user expectations. Satisfaction plays a significant role in a company when facing market competition[9].

\section{F. TAM Model}

XXX [10] TAM was discovered in 1980 because of the lack of available IT usage by the workers. The discoverer believed to improve workers' IT usage or acceptance is by interviewing individuals about their expectations in IT usage. By that knowledge, the organization will be able to conclude the factors to increase IT acceptance and usage. There are three main factors such as predict, and possibly control

(a) Technology Acceptance Model (TAM)

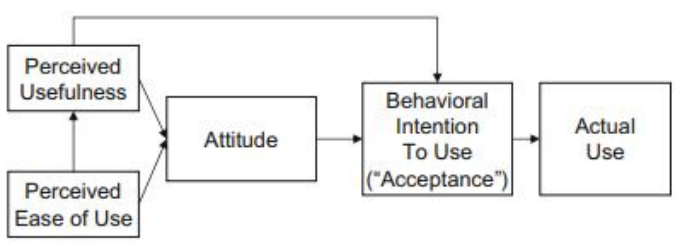

Figure 1: Technology Acceptance Model [11] 


\section{RESEARCH METHODOLOGY}

\section{A. Research Type}

In this research, data used is quantitative data which is patterned data that are collected using a distributed questionnaire to Video Conference application users located in Jakarta.

\section{B. Data Collection Technique}

This research is using a questionnaire data collection technique that is distributed to respondents in Jakarta. The questionnaire for this research is made online based on Google Form with 13 multiple choice questions and Likert scale from 1-5, where 1 represents "very disagree" and 5 represents "very agree"

The questionnaire that consists of 5 points Likert Scale has been used in many pieces of research. In previous research about the Course Experience Questionnaire in Indian Students Context, the questionnaire is addressed to indicate five characteristics and evaluate the quality of teaching in a certain scholastic program. The measurement is a gap indication in student's feelings between the teaching quality they got and what they need. (citation)

Based on previous research success, then in this research, we are also using the Likert Scale as the research calculation benchmark.[12]

\section{Analysis Method}

The analysis method in this research is using a sample with a purposive sampling technique. This research also using Structural Equation Modeling with Partial Least Square (SEM- PLS). SEM with PLS is an alternative technique on SEM analysis where the will be used data doesn't have to be a multivariate normal distribution. In SEM with PLS latent variable value can be estimated in accordance with the linear combination of manifest variables related to some latent variable and treated to replace manifest variable. The validity using Pearson R-Table with the level of significance is $5 \%$ and $\mathrm{N}=$ data.

This is known as the best method for measuring the relationship between interesting variables because it is based on the covariance method. It provides information about the size of the association, or correlation, as well as the direction of the relationship.

\section{RESULT AND DISCUSSION}

Based on our distributed questionnaire, data collected reached 308 respondents and it proved that there are 292 respondents stated they have or currently using Video Conference Application Zoom. There is $59.5 \%$ female gender who responded to the survey and $40.5 \%$ male gender. Then after futher analysis of the data there are $36,9 \%$ users are in the age range of 23-28 years old, $29,1 \%$ user in the age range of 29-32 years old, $18,1 \%$ user in the age range of 17-22 years old, $8,7 \%$ are users under 17 years old, the rest are other respondents $7,2 \%$ who are user above 33 years old.

Moreover, related to Video Conference Application Zoom users spread in Jakarta, the highest percentage of user are $27,2 \%$ in West Jakarta, then followed by user in Central Jakarta with percentage of $25,9 \%$, then $20,7 \%$ user in South Jakarta, then followed by user in East Jakarta with 15,9\%, then 9,4\% user in North Jakarta, and the rest are users from Kepulauan Seribu.

\section{A. Structural Model Design (Inner Model)}

- H1 : Perceived Ease of Use has a positive effect on Perceived Usefulness

- H2 : Perceived Ease of Use has a positive effect on Trust

- H3 : Trust has a positive effect on Perceived Userfullness

- H4 : Trust has a positive effect on Satisfaction

- H5 : Perceived Usefulness has a positive effect on Satisfaction

- H6 : Trust has a positive effect on Loyalty

- H7 : Perceived Usefulness has a positive effect on Loyalty

- H8 : Satisfaction has a positive effect on Loyalty

When the measurement evaluation model is done for Digital Video Streaming user respondents in Greater Jakarta, the used indicators that are not entirely valid and reliable. Therefore, it obtains the following structural model that suitable for this research:

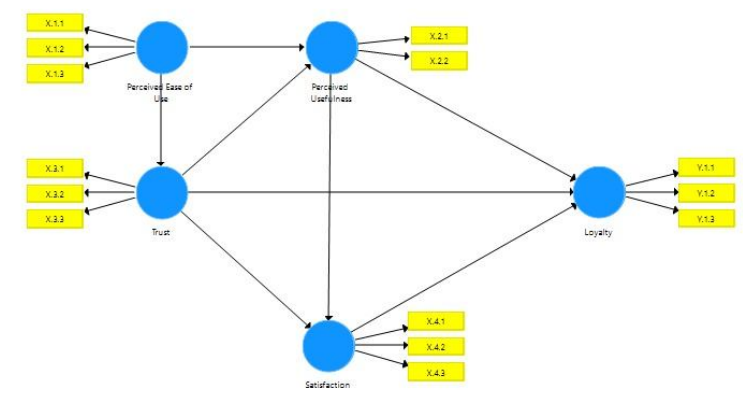

Figure 2: Research Model Design Source : Processed Output Smart PLS

\section{B. Measurement Model Evaluation (Outer Model)}

- Convergent Validity Test

Validity test for indicators can be done with the correlation between score indicators and construct indicators. Measurement with reflective indicators shows there was a change in certain indicators in a construct if other indicators in the construct have changed. 
Table 1: Output Result for Outer Loading

\begin{tabular}{|l|r|r|r|r|r|}
\hline & Loyalty & $\begin{array}{l}\text { Perceived } \\
\text { Ease of } \\
\text { Use }\end{array}$ & $\begin{array}{l}\text { Perceived } \\
\text { Usefulness }\end{array}$ & Satisfaction & Trust \\
\hline X.1.1 & & 0,803 & & & \\
\hline X.1.2 & & 0,608 & & & \\
\hline X.1.3 & & 0,777 & & & \\
\hline X.2.1 & & & 0,819 & & \\
\hline X.2.2 & & & 0,779 & & \\
\hline X.3.1 & & & & & 0,780 \\
\hline X.3.2 & & & & & $\mathbf{0 , 7 6 0}$ \\
\hline X.3.3 & & & & & $\mathbf{0 , 8 2 7}$ \\
\hline X.4.1 & & & & 0,794 & \\
\hline X.4.2 & & & & 0,735 & \\
\hline X.4.3 & & & & 0,797 & \\
\hline Y.1.1 & $\mathbf{0 , 8 1 2}$ & & & & \\
\hline Y.1.2 & $\mathbf{0 , 7 2 7}$ & & & & \\
\hline Y.1.3 & $\mathbf{0 , 7 6 4}$ & & & & \\
\hline
\end{tabular}

Source : Processed Output Smart PLS.

\section{- Discriminant Validity Test}

In a certain indicator, the discriminant validity test is necessary by comparing the value in a cross-loading table. Indicators will be stated as valid if it has loading factor value to the intended construct to be compared with loading factor value to another construct.

Table 2: Output Cross Loading

\begin{tabular}{|l|r|r|r|r|r|}
\hline & Loyalty & \multicolumn{1}{l|}{$\begin{array}{l}\text { Perceived } \\
\text { Ease of } \\
\text { Use }\end{array}$} & $\begin{array}{l}\text { Perceived } \\
\text { Usefulness }\end{array}$ & Satisfaction & Trust \\
\hline X.1.1 & 0,519 & 0,803 & 0,456 & 0,541 & 0,540 \\
\hline X.1.2 & 0,447 & 0,608 & 0,408 & 0,474 & 0,442 \\
\hline X.1.3 & 0,527 & 0,777 & 0,491 & 0,495 & 0,519 \\
\hline X.2.1 & 0,559 & 0,491 & 0,819 & 0,584 & 0,462 \\
\hline X.2.2 & 0,461 & 0,496 & 0,779 & 0,546 & 0,434 \\
\hline X.3.1 & 0,515 & 0,552 & 0,438 & 0,485 & 0,780 \\
\hline X.3.2 & 0,553 & 0,524 & 0,515 & 0,569 & 0,760 \\
\hline X.3.3 & 0,540 & 0,542 & 0,364 & 0,481 & 0,827 \\
\hline X.4.1 & 0,592 & 0,509 & 0,611 & 0,794 & 0,486 \\
\hline X.4.2 & 0,525 & 0,525 & 0,537 & 0,735 & 0,492 \\
\hline $\mathbf{X . 4 . 3}$ & 0,560 & 0,564 & 0,492 & 0,797 & 0,539 \\
\hline Y.1.1 & 0,812 & 0,580 & 0,548 & 0,568 & 0,594 \\
\hline Y.1.2 & 0,727 & 0,472 & 0,513 & 0,558 & 0,498 \\
\hline Y.1.3 & 0,764 & 0,510 & 0,403 & 0,538 & 0,469 \\
\hline
\end{tabular}

Source : Processed Output Smart PLS.
- Reliability Test

Some latent variables can be stated as having good reliability if it has a bigger reliability composite value than 0.7 and a bigger Cronbach's alpha value than 0.7 .

Table 3: Latent Reliability Variable Test Result

\begin{tabular}{|c|c|c|}
\hline & $\begin{array}{l}\text { Cronbach's } \\
\text { Alpha }\end{array}$ & $\begin{array}{l}\text { Composite } \\
\text { Reliability }\end{array}$ \\
\hline Loyalty & 0,653 & 0,812 \\
\hline $\begin{array}{l}\text { Perceived } \\
\text { Ease of Use }\end{array}$ & 0,564 & 0,776 \\
\hline $\begin{array}{l}\text { Perceived } \\
\text { Usefulness }\end{array}$ & 0,437 & 0,780 \\
\hline Satisfaction & 0,668 & $\mathbf{0 , 8 1 9}$ \\
\hline Trust & 0,698 & 0,832 \\
\hline
\end{tabular}

Source : Processed Output Smart PLS.

\section{Evaluasi Model Struktural (Inner Model)}

- $\mathrm{R}^{2}$ Test

$\mathrm{R}$-squared value $\mathrm{R}^{2}$ is used to measure how big certain independent latent variable impact on the dependent latent variable :

Table 4: $\mathrm{R}^{2}$ Calculation Output

\begin{tabular}{|c|c|c|}
\hline & R Square & $\begin{array}{l}\text { R Square } \\
\text { Adjusted }\end{array}$ \\
\hline Loyalty & 0,616 & 0,612 \\
\hline $\begin{array}{l}\text { Perceived } \\
\text { Usefulness }\end{array}$ & 0,416 & 0,412 \\
\hline Satisfaction & 0,595 & 0,592 \\
\hline Trust & 0,468 & 0,466 \\
\hline
\end{tabular}

Source : Processed Output Smart PLS.

- Significance Test

The significance Test on the SEM model with PLS intends to find out the influence of exogenous variables on the endogenous variable. Hypothesis test with SEM PLS method is done by performing the bootstrapping process with computer program smartPLS 3.0 help so can be obtained a relation of exogenous variable effect on the endogenous variable as the following: 
Table 5: Bootstrapping Research Data Calculation Result

\begin{tabular}{|l|c|c|c|c|c|}
\hline & Origi & $\begin{array}{l}\text { Sample } \\
\text { Mean } \\
\text { (M) }\end{array}$ & $\begin{array}{l}\text { Standard } \\
\text { Deviation } \\
\text { (STDEV) }\end{array}$ & $\begin{array}{l}\text { T Statistics } \\
(\mid \mathbf{O} / \text { STDEV|) }\end{array}$ & $\begin{array}{l}\mathbf{P} \\
\text { Values }\end{array}$ \\
\hline $\begin{array}{l}\text { Perceived } \\
\text { Ease of Use } \\
\text {-> } \\
\text { Perceived } \\
\text { Usefulness }\end{array}$ & 0,438 & 0,438 & 0,073 & 5,991 & $\mathbf{0 , 0 0 0}$ \\
\hline $\begin{array}{l}\text { Perceived } \\
\text { Ease of Use } \\
\text { - Trust }\end{array}$ & 0,684 & 0,686 & 0,048 & 14,112 & $\mathbf{0 , 0 0 0}$ \\
\hline $\begin{array}{l}\text { Perceived } \\
\text { Usefulness } \\
\text { - Loyalty }\end{array}$ & 0,192 & 0,188 & 0,085 & 2,255 & $\mathbf{0 , 0 2 5}$ \\
\hline $\begin{array}{l}\text { Perceived } \\
\text { Usefulness } \\
\text {-> } \\
\text { Satisfaction }\end{array}$ & 0,498 & 0,498 & 0,063 & 7,904 & $\mathbf{0 , 0 0 0}$ \\
\hline $\begin{array}{l}\text { Satisfaction } \\
\text { - Loyalty }\end{array}$ & 0,370 & 0,370 & 0,076 & 4,840 & $\mathbf{0 , 0 0 0}$ \\
\hline $\begin{array}{l}\text { Trust -> } \\
\text { Loyalty }\end{array}$ & 0,332 & 0,337 & 0,090 & 3,679 & $\mathbf{0 , 0 0 0}$ \\
\hline $\begin{array}{l}\text { Trust -> } \\
\text { Perceived } \\
\text { Usefulness }\end{array}$ & 0,261 & 0,262 & 0,076 & 3,441 & $\mathbf{0 , 0 0 1}$ \\
\hline $\begin{array}{l}\text { Trust -> } \\
\text { Satisfaction }\end{array}$ & 0,372 & 0,374 & 0,078 & 4,783 & $\mathbf{0 , 0 0 0}$ \\
\hline
\end{tabular}

Source : Processed Output Smart PLS.

\section{CONCLUSION}

The impact of the coronavirus outbreak on Jakarta residents is an enactment of large-scale social restrictions regulation to prevent virus transmission. Working from home also effecting an increase in video conference user data traffic.

In regards to the result of research on customer trust and satisfaction toward loyalty on Zoom video conference application shows that Perceived Ease of Use (X.1) variable is effecting Perceived Usefulness (X.2), Perceived Ease of Use (X.1) variable is effecting Trust (X.3) variable, Perceived Usefulness (X.2) variable is effecting Loyalty (Y.1) variable, Perceived Usefulness variable is effecting Satisfaction (X.4) variable, Satisfaction (X.4) variable is effecting Loyalty (Y.1) variable, Trust (X.3) variable is effecting Loyalty (Y.1) variable, Trust variable is effecting Perceived Usefulness (X.2) variable, dan Trust (X.3) variable is effecting Satisfaction (X.4) variable. The conclusion is all variables are effecting each other with each significantly available indicator.

\section{REFERENCES}

1. B. Septalisma. Pengguna Aplikasi Video Conference Imbas WFH di RI Meningkat, CNN Indonesia, Jakarta, p. 1, 24-Mar-2020.

2. F. A. Burhan. Keamanan Data Dikeluhkan Pengguna, Zoom Fokus Memperbaiki Privasi, Katadata.Co.Id, Jakarta, p. 1, 03-Apr-2020.

3. B. A. Alhlak, P. Ramakrisnan, Z. S. Hameed, and H. R. Mohseni. Video Conference: Integrated Tool for Identifying CSF in Education Development in UiTM,
Procedia - Soc. Behav. Sci., vol. 67, no. November 2011, pp. 102-113, 2012, doi: 10.1016/j.sbspro.2012.11.311.

4. Y.-C. Wu, C.-S. Chen, and Y.-J. Chan. Overview of The 2019 Novel Coronavirus (2019-nCoV), J. Chinese Med. Assoc., $\quad$ p. $\quad 1, \quad 2020, \quad$ doi: 10.1097/jcma.0000000000000270.

5. H. K. Dewi. Update Corona Indonesia, 17 April: 5.923 kasus positif, 607 sembuh, 520 meninggal, kontan.co.id, Jakarta, p. 1, 17-Apr-2020.

6. Anonymous. Blunder Aplikasi Zoom yang Populer di Tengah Pandemi COVID-19, VOI, Jakarta, p. 2, 03-Apr-2020.

https://doi.org/10.31605/ijes.v2i2.659

7. S. Utami. the Influence of Customers' Trust on Customer Loyalty, Int. J. Econ. Commer. Manag. United Kingdom, vol. III, no. 7, pp. 638-653, 2015, [Online]. Available: http://ijecm.co.uk/.

8. V. Leninkumar. The Relationship between Customer Satisfaction and Customer Trust on Customer Loyalty, Int. J. Acad. Res. Bus. Soc. Sci., vol. 7, no. 4, pp. 450-465, 2017, doi: 10.6007/ijarbss/v7-i4/2821.

9. L. Dewi. Customer Loyalty, Through Customer Satisfaction in Customers Pt. Xyz, J. Apl. Manaj., vol. 18, no. 1, pp. 189-200, 2020, doi: 10.21776/ub.jam.2020.018.01.19.

10. M. Adele, I. Eko, K. Raymond, and A. Hidayat, "Analysis of the factors that affecting intention to use Tourism Online Booking," Int. J. Adv. Trends Comput. Sci. Eng., vol. Volume 8, 2019, [Online]. Available: http://www.warse.org/IJATCSE/static/pdf/file/ijatcse04 862019.pdf. https://doi.org/10.30534/ijatcse/2019/04862019

11. R. J. Holden and B. T. Karsh. The Technology Acceptance Model: Its past and its future in health care, J. Biomed. Inform., vol. 43, no. 1, pp. 159-172, 2010, doi: 10.1016/j.jbi.2009.07.002.

12. A. Dumka and E. Studie, "International Journal of Advanced Trends in Computer Science and Engineering Service Implementation using MPLS VPN in IPv6," vol. 2, no. 4, pp. 95-97, 2013. 